\title{
HARNESSING THE POTENTIAL OF MEDICINAL PLANTS USED FOR THE TREATMENT OF DIABETES IN RURAL AREAS OF AZAD JAMMU AND KASHMIR, PAKISTAN
}

\author{
Begum, S. ${ }^{1}-$ Hussain, S. $^{2}-$ Mehmood, A..$^{2 *}$ Ahmad, K. S. ${ }^{2}-$ HAmID, A. ${ }^{3}$ \\ ${ }^{I}$ Department of Botany, Government College (GC) University, Lahore, Pakistan \\ ${ }^{2}$ Department of Botany, University of the Poonch Rawalakot (UPR), Azad Kashmir 12350, Pakistan \\ ${ }^{3}$ Department of Horticulture, University of the Poonch Rawalakot, Azad Kashmir 12350, Pakistan \\ (phone: +92-34-6538-7843; fax: +92-58-3496-0073) \\ *Corresponding author \\ e-mail: ansar.mehmood321@gmail.com \\ (Received 22 ${ }^{\text {nd }}$ Jun 2018; accepted $14^{\text {th }}$ Aug 2018)
}

\begin{abstract}
This study was aimed to highlight the significance of medicinal plants, used for the treatment of diabetes from Azad Jammu and Kashmir, Pakistan. A total of 340 informants including 171 males and 169 females were interviewed through questionnaire. For reliability of medicinal knowledge, relative frequency of citation (RFC) and family importance value (FIV) were calculated. Novelty of the work was found out with the help of Jaccard index (JI). RFC and FIV were further analysed by multivariate cluster analysis. A total of 42 plant species belonging to 41 genera and 30 families were recorded during the survey. Leaves were the most commonly used plant part and decoction was the most recommended remedy preparation method. Momodica charantia, Berberis lycium, Syzygium cumini and Oxalis corniculata were the most cited species with relative frequency of citation $0.81,0.72,0.59$ and 0.55 respectively. The highest consensus between informants and indigenous uses of family was shown by Lamiaceae with 97.44 FIV followed by Fabaceae (87.05) and Myrtaceae (85.88). Novelty index showed that Berberis lycium, Beta vulgaris, Coriandrum sativum and Oxalis corniculata were the newly documented species against diabetes. The results of present study could play vital role in conservation of traditional knowledge of study area.
\end{abstract}

Keywords: medicinal knowledge, cluster analysis, traditional knowledge, Jaccard index, Berberis lycium

\section{Introduction}

Diabetes is a major public health problem currently affecting 284.6 million people worldwide and according to the latest International Diabetes Federation estimates it is expected to affect 438.4 million adults by 2030 becoming one of the world's main disabler and killer (IDF, 2010). It disturbs the function of heart, eyes, kidneys and overall body. It is a major health problem that results in reduced life quality and increased illness (Wei et al., 2010). Diabetes is usually managed by diet, exercise, oral hypoglycemic agents and insulin (Ayodhya et al., 2013).

In addition to modern allopathic treatments, plants have also been used for the treatment of diabetes throughout the world in traditional systems of medicines (Donga et al., 2015). Many plants have the potential to lower the blood glucose level and to manage diabetes mellitus like Morinda citrifolia (Goodman and Ghafoor, 1992), Musa sapientum (Jain et al., 1998)), Allium cepa (Mossa, 1999), Brassica juncea (Yokozawa, 2003), Herichrysum odoratissimum, Herichrysum petiolare, Hypoxis hemerocallidea and Hypoxis colchicifolia (Masika and Afoloayan, 2003). The rural inhabitants of Azad Jammu and Kashmir are mostly depend on traditional medicines and traditional health 
practitioners as the primary source of health care. There are several reports of ethnobotanical surveys in Azad Jammu and Kashmir (Ajaib et al., 2015; Ajaib and Khan, 2014; Mahmood et al., 2011) concerning use of medicinal plants for the management and treatment of diseases including diabetes mellitus. However, in Azad Jammu and Kashmir, the traditional medicinal plants that are used for the treatment of diabetes are not studied in great detail.

Pakistan is ranked $7^{\text {th }}$ in the world for the diabetes prevalence. A recent diabetes prevalence survey has revealed staggering 16.98 percent prevalence of diabetes as 35.3 million people among the adult population are found diabetic in Pakistan. If awareness programs and proper treatment are not adopted, Pakistan may have double of diabetic patients by 2040 (WHO, 2016). Such high prevalence of diabetes calls for continued efforts to improve public awareness regarding the disease. Keeping in view the current scenario of diabetes, the present study was designed to document plant knowledge used exclusively for the treatment of diabetes in rural areas of Azad Jammu and Kashmir, Pakistan.

\section{Materials and methods}

\section{Study area}

The Himalaya, the emporium of biodiversity, have been variously divided into Western Himalaya, Central Himalaya and Eastern Himalaya. Azad Kashmir $\left(34.22^{\circ} \mathrm{N}\right.$ $73.28^{\circ} \mathrm{E}$ ) is located in foothills of Western Himalaya with an area of $13,269 \mathrm{~km}^{2}$ which is divided into two distinct geographical zones. North and East are mostly hilly and mountainous while South and West are valleys and plains (Fig. 1). Due to extensive topographical variations, the area supports a variety of plant species (Afshan et al., 2011). In Himalaya, about $70 \%$ of flora have medicinal value and rural population largely depends on these plants for medicines (Shaheen et al., 2012). These plants based on traditional medicine system, continue to play an essential role in health care, with about $80 \%$ of the world's inhabitants relying mainly on traditional medicines for their primary health care (Franz, 1985). Till date, 6000 species are identified from different parts of Pakistan and Azad Kashmir, and off these, more than 400 species are only dwelling only in Azad Kashmir region with high medicinal values (Shinwari and Shinwari, 2010). In remote areas about $60 \%$ of the local population is engaged in collection and processing of different medicinal herbs (Qamar et al., 2010).

\section{Field study}

A wide-ranging survey in rural and remote areas was carried out during 2013-15. Information was gathered using open and close ended questioners. A sum of 340 informants including 171 males and 169 females were interviewed after initial survey and many group discussions with the native people. Selection criteria of choosing informants were based on the individual's expertise in the collection and utilization of medicinal plants for diabetes. Prior Informed Consent was obtained from informants involved in interviews and plant collection walks. Ethical approval was not required for this study as research participants were only interviewed on knowledge of plant species used for medicinal purposes. Participants were not subjected to any treatment, were not part of any clinical trials, and no information is presented here that could identify individual participants. Plant samples were collected, pressed with the help of plant 
presser and dried at room temperature. Completely dried plant specimens were mounted on the herbarium sheets. For long term preservation and to avoid fungal attack, each mounted sample was treated with $1 \% \mathrm{HgCl}_{2}$ preservative. Plants were identified by the plant taxonomist at The Department of Botany and further clarification was done through herbaria comparison and available taxonomic literature. The International Plant Name Index (IPNI), Scopus, Web of Science and Google Scholar, Catalog of vascular plants of West Pakistan and Kashmir (Ali and Nasir, 1970-2002) were also consulted to obtain correct botanical names. Plant specimens with voucher number were deposited in Herbarium of University of the Poonch Rawalakot.

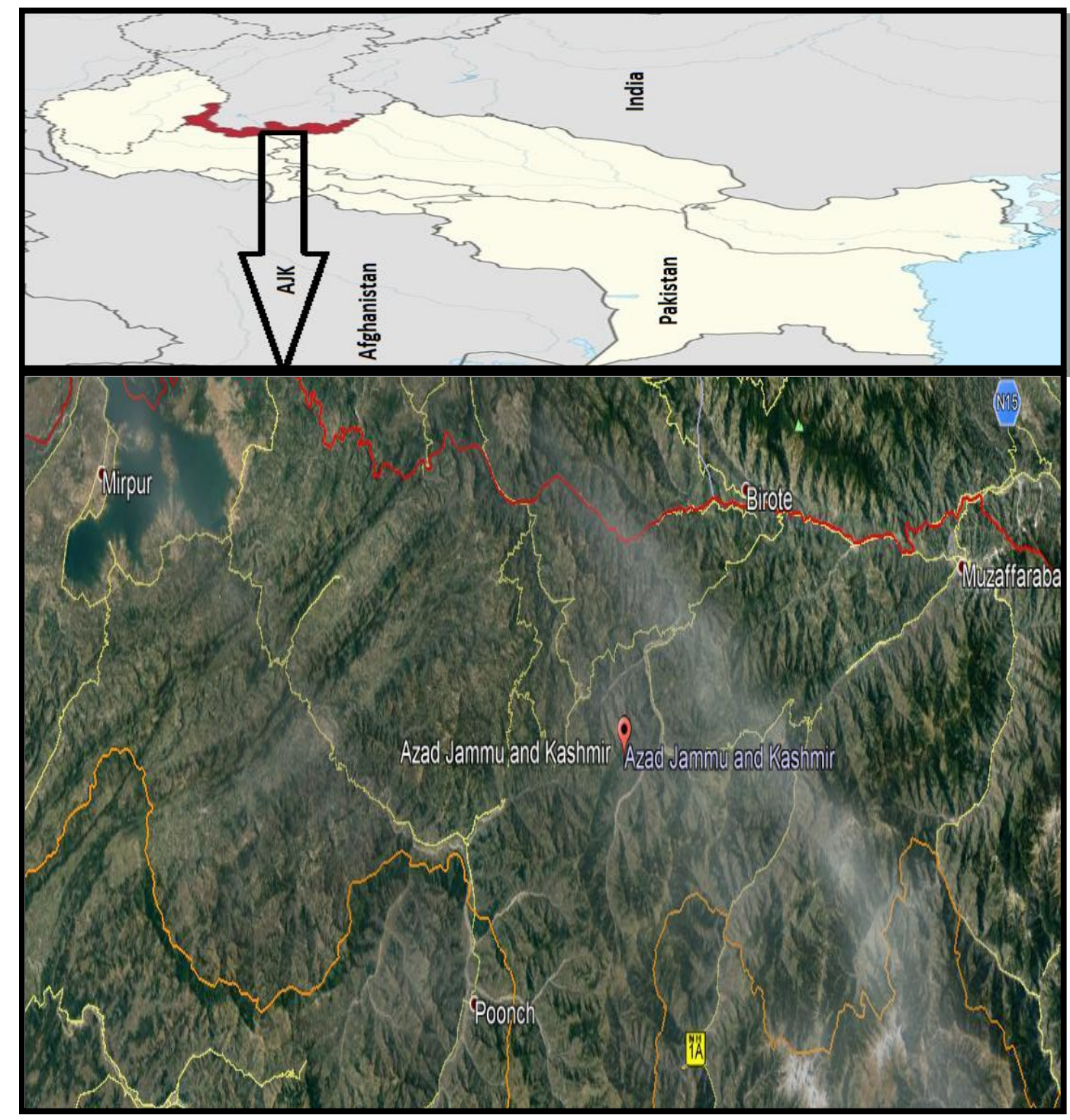

Figure 1. Map of the study area (AJK)

\section{Data collection}

Data was collected from people of different age groups belonging to different professions (formers, shopkeepers, teachers, herbal practitioners, wood sellers, students etc.) by using semi structured questionnaire (see Appendix), developed by using the 
method of Edwards et al. (2005). The collected data comprised of local names of the plants, the parts of plant, recipe and usage method, quantity of dose and duration of treatment.

\section{Relative frequency of citation}

The frequency of citation was calculated to assess the incidence of one particular plant species used for the treatment of diabetes in relation to the overall citations for all plants. The relative frequency of citation for a plant species was calculated as Equation 1 (Tardio and Pardo-de-Santayana, 2008).

$$
\mathrm{RFC}=\frac{\mathrm{FC}}{\mathrm{N}}(0<R F C<1)
$$

Where FC is the number of informants who mentioned the use of plant and $\mathrm{N}$ is the total number of informants.

\section{Family importance value}

The consensus between informants and indigenous use of family was evaluated by formula in Equation 2 (Molares and Ladio, 2009)

$$
\mathrm{FIV}=\mathrm{FC}_{\text {Family }} / \mathrm{N} \times 100
$$

Where $\mathrm{FC}=$ Number of informants mentioned indigenous use of family for particular disease and $\mathrm{N}=$ total number of informants mentioning all family for particular disease.

\section{Jaccard index}

JI was used to find the resemblance in indigenous data among various ethnic groups and geographical areas by comparing present study with published works from the neighboring areas as in Equation 3 (Gonza et al., 2008).

$$
\mathrm{JI}=\frac{\mathrm{c} \times 100}{(\mathrm{a}+\mathrm{b})-\mathrm{c}}
$$

where $\mathrm{a}$ is the species present in our area only, $\mathrm{b}$ is the species present in neighboring area only and $\mathrm{c}$ is the species found in both areas.

\section{Data analysis}

Measuring the importance of plants and vegetation to people is a central concern in quantitative ethnobotany. Quantitative indices help to obtain quality information on medicinal plant usage which in turn contributes conservation of natural resources. Furthermore, such indices helped to establish consensus on which species are effective to cure diabetes, as well as the species' relative importance and enabled us to understand the extent of the potential utilization of each species. In this study, data ethnobotanical data was tested using quantitative indices namely: RFC, FIV, and JI. Multivariate cluster analysis was done on RFC and FIV. 


\section{Results}

\section{Demographic profile}

The present study was conducted in rural areas of Azad Jammu and Kashmir, Pakistan. A total of 340 informants have been interviewed (Table 1). The demographic profile of the area showed that there were $51 \%$ male and $49 \%$ female respondents. All the informants were classified into 3 age groups viz. Below 30 years (20\%), 30 to 50 years $(27 \%)$ and above 50 years $(56 \%)$. It was observed that indigenous knowledge was more confined to older people.

Table 1. Demographic data of the informants

\begin{tabular}{c|c|c|c}
\hline Variable & Categories & Total & \% \\
\hline \multirow{2}{*}{ Gender } & Male & 175 & 51 \\
& Female & 165 & 49 \\
\hline \multirow{3}{*}{ Age groups } & Below 30 & 69 & 20 \\
& $30-50$ & 91 & 27 \\
& Above 50 & 190 & 56 \\
\hline
\end{tabular}

\section{Documentation of plants}

The ethnobotanical data showed that inhabitants of Azad Jammu and Kashmir use 42 plant species belonging to 41 genera and 30 families for the treatment of diabetes. Most of them were angiosperms while gymnosperms and pteridophytes are represented by only one species each. All the recorded plant species are arranged in alphabetical order with their families, voucher specimen, local name, part used and recipes (Table 2).

Table 2. Documentation of medicinal plants used for the treatment of diabetes mellitus in Azad Jammu and Kashmir, Pakistan with scientific names, local names, parts used, recipe, $F C$ and $R F C$

\begin{tabular}{c|c|c|c|c|c|c}
\hline S. No. & Taxon & Local name & Part used & Recipe & FC & RFC \\
\hline 1 & $\begin{array}{c}\text { Acacia arabica Willd. } \\
\text { (Fabaceae) }\end{array}$ & Keeker & Pods, leaves, gum & Decoction & 13 & 0.03 \\
\hline 2 & $\begin{array}{c}\text { Aconitum heterophyllum } \\
\text { Wall. (Ranunculaceae) }\end{array}$ & Patrees & $\begin{array}{c}\text { Underground stem } \\
\text { and roots }\end{array}$ & Decoction, powder & 21 & 0.06 \\
\hline 3 & $\begin{array}{c}\text { Ajuga bracteosa Wall. } \\
\text { (Lamiaceae) }\end{array}$ & Kori booti & Whole plant & Decoction & 113 & 0.33 \\
\hline 5 & $\begin{array}{c}\text { Ajuga parviflora L. } \\
\text { (Lamiaceae) }\end{array}$ & Adamjan & Whole plant & Decoction & 70 & 0.20 \\
\hline 6 & $\begin{array}{c}\text { Aloe barbadensis Mill } \\
\text { (Liliaceae) }\end{array}$ & $\begin{array}{c}\text { Kanwar } \\
\text { gandal }\end{array}$ & Fresh leaves & Leaf juice & 57 & 0.16 \\
\hline
\end{tabular}




\begin{tabular}{|c|c|c|c|c|c|c|}
\hline 7 & $\begin{array}{l}\text { Avena sativa } \mathrm{L} . \\
\text { (Poaceae) }\end{array}$ & Jei & Seeds, roots & $\begin{array}{l}\text { Extracts of straws and } \\
\text { roots, seeds as powder }\end{array}$ & 12 & 0.03 \\
\hline 8 & $\begin{array}{l}\text { Bauhinia variegata } \mathrm{L} . \\
\text { (Fabaceae) }\end{array}$ & Kachnar & $\begin{array}{l}\text { Leaves, flower, } \\
\text { bark }\end{array}$ & Decoction & 80 & 0.23 \\
\hline 9 & $\begin{array}{l}\text { Berberis lycium L. } \\
\text { (Berberidaceae) }\end{array}$ & Simloo & Root bark & $\begin{array}{l}\text { Dried root, bark } \\
\text { powder and Juice }\end{array}$ & 257 & 0.75 \\
\hline 10 & $\begin{array}{l}\text { Beta vulgaris L. } \\
\text { (Chenopodiaceae) }\end{array}$ & Chuqander & $\begin{array}{l}\text { Tap root, leaves, } \\
\text { seeds }\end{array}$ & Juice and decoction & 136 & 0.40 \\
\hline 11 & $\begin{array}{r}\text { Caltha palustris } \mathrm{L} . \\
\text { (Ranunculaceae) }\end{array}$ & $\begin{array}{l}\text { Marsh } \\
\text { marigold }\end{array}$ & Aerial parts & Decoction & 45 & 0.13 \\
\hline 12 & $\begin{array}{l}\text { Catharanthus roseus } \\
\text { L.(Apocynaceae) }\end{array}$ & Madaguscar & Leaves, roots & Decoction and extract & 33 & 0.09 \\
\hline 13 & $\begin{array}{l}\text { Cedrus deodara Roxb. } \\
\text { (Pinaceae) }\end{array}$ & Deodar & $\begin{array}{l}\text { Leaves extract, } \\
\text { heart wood oil }\end{array}$ & $\begin{array}{c}\text { Heart wood and dried } \\
\text { leaves decoction }\end{array}$ & 88 & 0.25 \\
\hline 14 & $\begin{array}{l}\text { Chenopodium album } \mathrm{L} \\
\text { (Chenopodiaceae). }\end{array}$ & Bathuwa & Leaves, seeds & $\begin{array}{l}\text { Leaves as vegetable } \\
\text { and dry seeds orally } \\
\text { with water }\end{array}$ & 29 & 0.08 \\
\hline 15 & $\begin{array}{c}\text { Coriandrum sativum } \mathrm{L} . \\
\text { (Apiaceae) }\end{array}$ & Dhaniyan & Leaves, fruit & $\begin{array}{c}\text { Leaves as salad and } \\
\text { fruits are taken with } \\
\text { water }\end{array}$ & 139 & 0.40 \\
\hline 16 & $\begin{array}{c}\text { Cuscuta reflexa } \\
\text { Roxb.(Convolvulaceae) }\end{array}$ & Neeladhari & Whole plant & $\begin{array}{l}\text { Decoction of dry and } \\
\text { fresh plant }\end{array}$ & 32 & 0.09 \\
\hline 17 & $\begin{array}{c}\text { Equisetum hyemale L. } \\
\text { (Equistaceae) }\end{array}$ & $\begin{array}{l}\text { Commen } \\
\text { horsetail }\end{array}$ & Whole plant & $\begin{array}{l}\text { Decoction of dried } \\
\text { plant }\end{array}$ & 10 & 0.02 \\
\hline 18 & $\begin{array}{l}\text { Eriobotrya japonica } \\
\text { Thumb. (Rosaceae) }\end{array}$ & Loquat & Leaves, flower, fruit & $\begin{array}{l}\text { Dry leaves extracts } \\
\text { and decoction }\end{array}$ & 10 & 0.02 \\
\hline 19 & $\begin{array}{l}\text { Fragaria vesca } \mathrm{L} . \\
\quad \text { (Rosaceae) }\end{array}$ & Kanachi & Roots, leave & $\begin{array}{l}\text { Decoction of dried and } \\
\text { fresh roots and leaves }\end{array}$ & 18 & 0.05 \\
\hline 20 & $\begin{array}{l}\text { Hedra helix } \mathrm{L} . \\
\text { (Araliaceae) }\end{array}$ & Herbambel & Leaves & $\begin{array}{c}\text { Powder and decoction } \\
\text { of shade dried leaves }\end{array}$ & 136 & 0.40 \\
\hline 21 & $\begin{array}{l}\text { Juglans regia L. } \\
\text { (Juglandaceae) }\end{array}$ & Akhore & Leaves, bark, fruit & $\begin{array}{c}\text { Decoction of dried } \\
\text { leaves and bark, fruit } \\
\text { oil }\end{array}$ & 32 & 0.09 \\
\hline 22 & $\begin{array}{l}\text { Lycium barbarum L. } \\
\text { (Solanaceae) }\end{array}$ & Kankoli & Ripe fruit & Ripe fruit & 111 & 0.32 \\
\hline 23 & $\begin{array}{l}\text { Marrubiam vulgare } \mathrm{L} . \\
\quad \text { (Lamiaceae) }\end{array}$ & $\begin{array}{c}\text { White } \\
\text { horehound }\end{array}$ & Leaves, roots & $\begin{array}{c}\text { Extracts of dry leaves } \\
\text { and roots }\end{array}$ & 63 & 0.18 \\
\hline 24 & $\begin{array}{c}\text { Mentha arvensis } \mathrm{L} . \\
\text { (Lamiaceae) }\end{array}$ & Podina & Aerial parts & $\begin{array}{l}\text { Decoction and sauce } \\
\text { of fresh or dry leaves }\end{array}$ & 87 & 0.25 \\
\hline
\end{tabular}




\begin{tabular}{|c|c|c|c|c|c|c|}
\hline 25 & $\begin{array}{c}\text { Momordica charantia } \mathrm{L} . \\
\text { (Cucurbitaceae) }\end{array}$ & Karela & Fruit, seeds, leaves & $\begin{array}{l}\text { Seed oil and leaves } \\
\text { decoction }\end{array}$ & 277 & 0.81 \\
\hline 26 & $\begin{array}{c}\text { Nasturtium officinale L. } \\
\text { (Brassicaceae) }\end{array}$ & Chow & Aerial parts & Used as vegetable & 123 & 0.36 \\
\hline 27 & $\begin{array}{l}\text { Olea europaea L. } \\
\text { (Oleaceae) }\end{array}$ & Zeytoon & Leaves, seeds & $\begin{array}{l}\text { Decoction of dried } \\
\text { leaves and seeds }\end{array}$ & 153 & 0.45 \\
\hline 28 & $\begin{array}{l}\text { Oxalis corniculata L. } \\
\quad \text { (Oxalidaceae) }\end{array}$ & Khatkoira & Whole plant & $\begin{array}{l}\text { Juice and decoction of } \\
\text { fresh leaves and roots }\end{array}$ & 189 & 0.55 \\
\hline 29 & $\begin{array}{l}\text { Phaseulus vulgaris L. } \\
\text { (Fabaceae) }\end{array}$ & Lobia & Beans & $\begin{array}{c}\text { Pods and bean sauce } \\
\text { vegetable }\end{array}$ & 113 & 0.33 \\
\hline 30 & $\begin{array}{l}\text { Plantago lanceolata } \mathrm{L} . \\
\text { (Plantaginaceae) }\end{array}$ & $\begin{array}{l}\text { Chamch-e- } \\
\text { Pattar }\end{array}$ & Whole plant, seeds & $\begin{array}{l}\text { Seeds decoction, } \\
\text { leaves as vegetable }\end{array}$ & 151 & 0.44 \\
\hline 31 & $\begin{array}{l}\text { Polygonum aviculare } \\
\text { L.(Polygonaceae) }\end{array}$ & Masloon & Whole plant & $\begin{array}{l}\text { Decoction of fresh or } \\
\text { dried plant }\end{array}$ & 109 & 0.32 \\
\hline 32 & $\begin{array}{l}\text { Psidium guajava L. } \\
\text { (Myrtaceae) }\end{array}$ & Amrood & Fruit, leaves, roots & $\begin{array}{c}\text { Fresh leaves juice and } \\
\text { dry leaves extract }\end{array}$ & 91 & 0.26 \\
\hline 33 & $\begin{array}{c}\text { Quercus dilatata Thumb. } \\
\text { (Fagaceae) }\end{array}$ & Burri & Bark & Bark decoction & 10 & 0.02 \\
\hline 34 & $\begin{array}{c}\text { Rehmannia glutinosa } \\
\text { Gaertn. } \\
\text { (Scrophulariaceae) }\end{array}$ & $\begin{array}{l}\text { Chandal } \\
\text { booty }\end{array}$ & Roots & Decoction & 49 & 0.14 \\
\hline 35 & $\begin{array}{l}\text { Solanum nigrum L. } \\
\text { (Solanaceae) }\end{array}$ & Kach Maach & Whole plant, fruit & Decoction and extract & 29 & 0.08 \\
\hline 36 & $\begin{array}{l}\text { Syzygium cumini L. } \\
\text { (Myrtaceae) }\end{array}$ & Jaman & Leaves, seeds, fruit & $\begin{array}{l}\text { Powder orally with } \\
\text { water }\end{array}$ & 201 & 0.59 \\
\hline 37 & $\begin{array}{c}\text { Taraxacum officinale L. } \\
\text { (Asteraceae) }\end{array}$ & Hund & Whole plant & $\begin{array}{c}\text { Leaves as vegetable, } \\
\text { decoction of dried } \\
\text { plant }\end{array}$ & 139 & 0.40 \\
\hline 38 & $\begin{array}{c}\text { Trigonella foenum- } \\
\text { gracum L. (Fabaceae) }\end{array}$ & Methi & Leaves and seeds & $\begin{array}{l}\text { Leaves fresh as } \\
\text { vegetable and seed } \\
\text { decoction or extract }\end{array}$ & 80 & 0.23 \\
\hline 39 & $\begin{array}{l}\text { Urtica dioica } \mathrm{L} . \\
\text { (Urticaceae) }\end{array}$ & $\begin{array}{l}\text { Bichhu } \\
\text { booty }\end{array}$ & Roots & $\begin{array}{c}\text { Hot water extracts of } \\
\text { dried roots }\end{array}$ & 17 & 0.05 \\
\hline 40 & $\begin{array}{c}\text { Woodfordia fruticosa } \mathrm{L} . \\
\text { (Lythraceae) }\end{array}$ & Bela, Davi & Flowers & Dried flower extract & 10 & 0.02 \\
\hline 41 & $\begin{array}{l}\text { Zanthoxylum alatum } \\
\text { Roxb. (Rutaceae) }\end{array}$ & Timber & $\begin{array}{l}\text { Bark, fruits and } \\
\text { leaves }\end{array}$ & $\begin{array}{l}\text { Extracts of all dried } \\
\text { parts }\end{array}$ & 38 & 0.11 \\
\hline 42 & $\begin{array}{l}\text { Zizpiphus mauritiana } \\
\text { Lam. (Rhamnaceae) }\end{array}$ & Beri. & Fruits and leaves & $\begin{array}{c}\text { Mixture of dried fruit } \\
\text { and leaves extracts }\end{array}$ & 76 & 0.22 \\
\hline
\end{tabular}




\section{Family participation}

It was found that most dominant families with respect to species number were Fabaceae and Lamiaceae with 4 species each followed by Apiaceae, Chenopodiaceae, Ranunculaceae, Rosaceae and Solanaceae with 2 species each (Fig. 2). All other families were represented with one species. The dominance of the families is corresponded to the fact that these are well known among the people and easy to access.

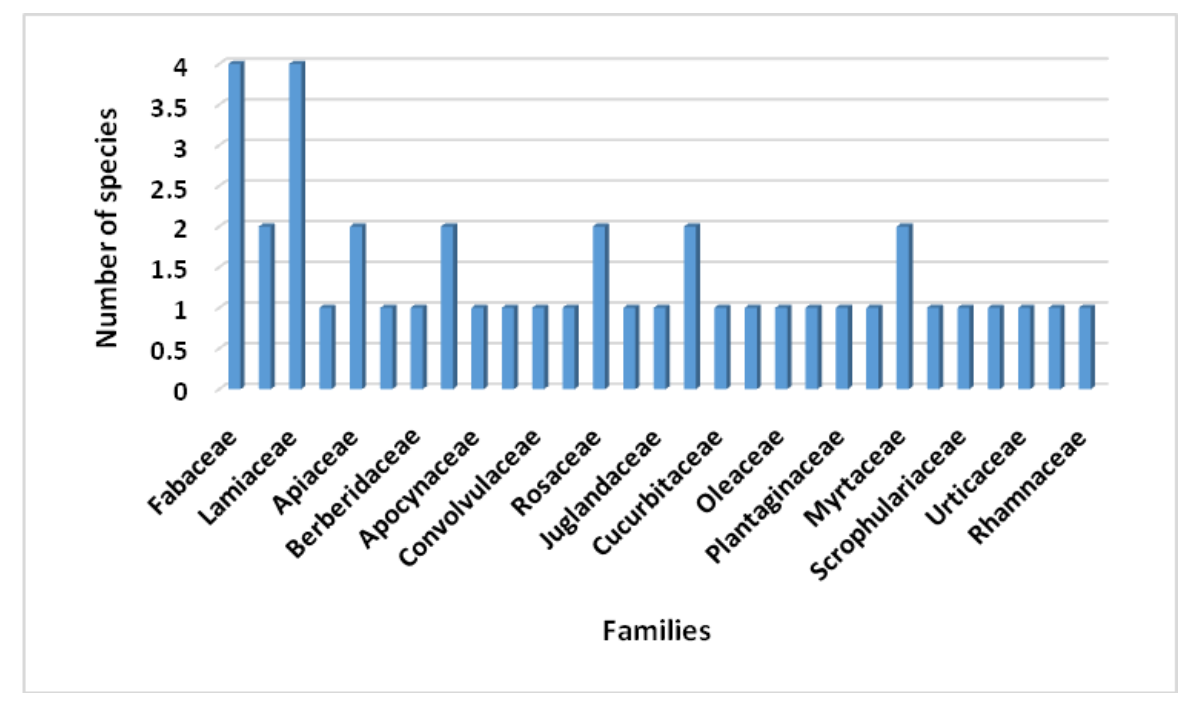

Figure 2. Number of species per family

\section{Parts used and methods of administration}

Most frequently used plant parts were the leaves (28\%) and fruits (16\%) followed by whole plant (13\%), seeds (12\%), roots $(10 \%)$, bark (7\%), flowers $(4 \%)$ and aerial parts (3\%) as shown in Figure 3. Herbal medicines were prepared by using different preparation methods, i.e. decoction, powder, juice, extract and vegetable (Fig. 4). Most frequent used method was decoction $(48 \%)$ followed by extract $(21 \%)$, juice and vegetable (11\% each) and powder (9\%) as presented in Figure 4.

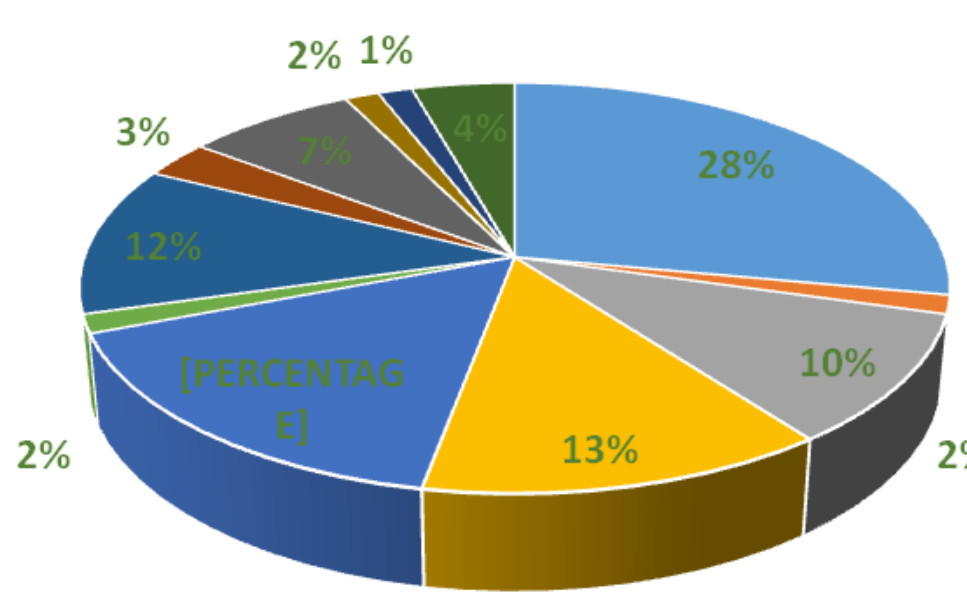

Figure 3. Plant parts used to treat diabetes

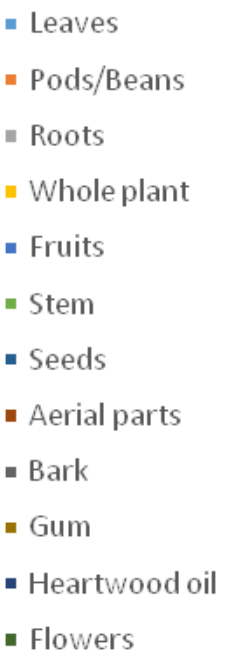

- Flowers 


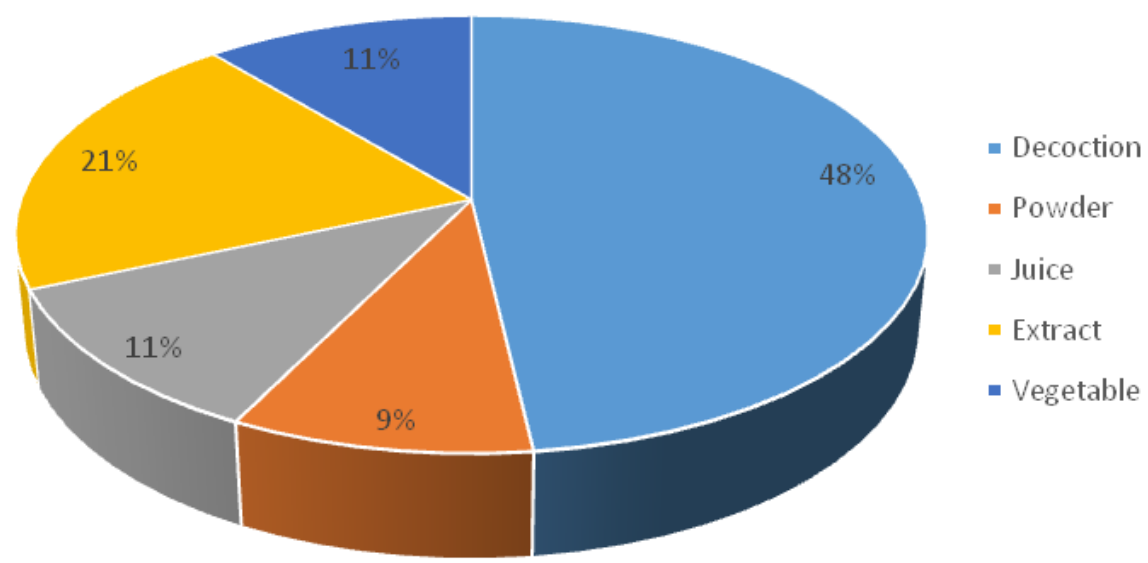

Figure 4. Methods of herbal drug preparation

\section{Relative frequency of citation}

Most common plants used to treat diabetes as mention by informants were determined by calculating RFC. The RFC values were shown in Table 2, which ranged from 0.09 to 0.95 . The highest RFC was found for Berberis lycium (0.95) followed by Momordica charantia (0.91) and Beta vulgaris (0.80).

\section{Family importance value}

The results of FIV are shown in Table 3. The highest consensus between informants and indigenous uses of family was shown by Lamiaceae with 97.44 FIV followed by Fabaceae (87.05), Myrtaceae (85.88), Cucurbitaceae (81.47), Berberidaceae (75.58) and Apiaceae (71.17).

Table 3. Family importance value

\begin{tabular}{c|c|c}
\hline Family & FC & FIV \\
\hline Equitaceae & 10 & 2.94 \\
Lythraceae & 10 & 2.94 \\
Polygonaceae & 109 & 32.05 \\
Poaceae & 12 & 3.52 \\
Brassicaceae & 123 & 36.17 \\
Araliaceae & 136 & 40 \\
Asteraceae & 139 & 40.88 \\
Solanaceae & 140 & 41.17 \\
Plantaginaceae & 151 & 44.41 \\
Oleaceae & 153 & 45.00 \\
Chenopodiaceae & 165 & 48.52 \\
Urticaceae & 17 & 50.00 \\
oxalidaceae & 189 & 55.58 \\
Apiaceae & 242 & 71.17 \\
Berberidaceae & 257 & 75.58
\end{tabular}




\begin{tabular}{c|c|c} 
Cucurbitaceae & 277 & 81.47 \\
Rosaceae & 28 & 8.23 \\
Myrtaceae & 292 & 85.88 \\
Fabaceae & 296 & 87.05 \\
Convolvulaceae & 32 & 9.41 \\
Juglandaceae & 32 & 9.41 \\
Apocynaceae & 33 & 9.70 \\
Lamiaceae & 333 & 97.94 \\
Rutaceae & 38 & 11.17 \\
Scrophulariaceae & 49 & 14.41 \\
Liliaceae & 57 & 16.76 \\
Ranunculaceae & 66 & 19.41 \\
Rhamnaceae & 76 & 22.35 \\
Pinaceae & 88 & 25.88 \\
\hline
\end{tabular}

\section{Jaccard index}

It was used to compare the indigenous knowledge use to treat diabetes among different communities as the ethnobotanical knowledge greatly vary among the communities because of different origins, geography, culture and social behavior. This comparison of knowledge may result in discovery of many new drugs (Leonti, 2011). The present study was compared with 9 other studies from Pakistan, India, Bangladesh, Iran (Table 4). The maximum degree of parallel index was found with studies by Bahmani et al., (Bahmoni et al., 2014) from Uramia, Northwest Iran, Ahmad et al. (2009) Attock Pakistan and Kumari et al. (2011) Uttarakhand, India.

Table 4. Jaccard index comparing present study with previous studies

\begin{tabular}{|c|c|c|c|c|c|c|c|}
\hline 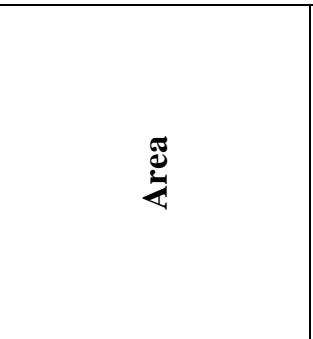 & 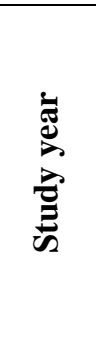 & 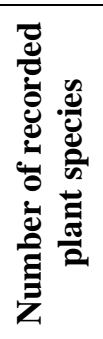 & 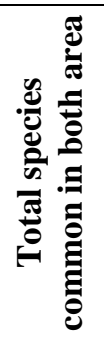 & 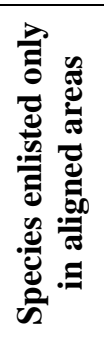 & 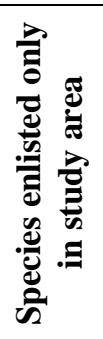 & 三 & \\
\hline Attock, Pakistan & 2009 & 37 & 5 & 32 & 37 & 7.81 & Ahmad et al., 2009 \\
\hline Tamil Nadu, India & 2017 & 65 & 5 & 60 & 37 & 5.43 & Aadhan and Anand, 2017 \\
\hline Uttarakhand, India & 2011 & 16 & 3 & 13 & 39 & 6.12 & Kumari et al., 2011 \\
\hline Dhaka, Bangladesh & 2013 & 37 & 3 & 34 & 39 & 4.29 & Ocvirk et al., 2013 \\
\hline $\begin{array}{l}\text { Madhya Pradesh, } \\
\text { India } \\
\end{array}$ & 2012 & 28 & 1 & 27 & 41 & 1.49 & Yadav et al., 2012 \\
\hline $\begin{array}{c}\text { Taroudant Province, } \\
\text { Morocco }\end{array}$ & 2017 & 39 & 4 & 35 & 38 & 5.80 & Katiri et al., 2017 \\
\hline $\begin{array}{l}\text { Tamilnadu, Southern } \\
\text { India }\end{array}$ & 2012 & 16 & 2 & 14 & 40 & 3.85 & $\begin{array}{c}\text { Elavarasi and Saravanan, } \\
2012\end{array}$ \\
\hline $\begin{array}{l}\text { Urmia, Northwest } \\
\text { Iran }\end{array}$ & 2014 & 30 & 5 & 25 & 37 & 8.77 & Bahmani et al., 2014 \\
\hline
\end{tabular}




\section{Novelty and future impact}

The novelty index was determined by comparing present study with previous studies conducted in Pakistan, India, Bangladesh and Iran as shown in Table 3. In Azad Jammu and Kashmir, no previous study was found on anti-diabetes uses of medicinal plants. In Pakistan only few studies were found. There was very little resemblance with previous studies in uses of plants to treat diabetes. Some of the newly documented medicinal plants used to treat diabetes were Berberis lycium, Beta vulgaris, Coriandrum sativum, Oxalis corniculata, Phaseulus vulgaris, Psidium guajava, Zizpiphus mauritiana, Mentha arvensis, Hedra helix, Bauhinia variegata, Taraxacum officinale and Zanthoxylum alatum.

\section{Multivariate cluster analysis}

Based upon RFC values, multivariate cluster analysis results reveal significant relationship among plant species. There were two main clusters (Fig. 5).

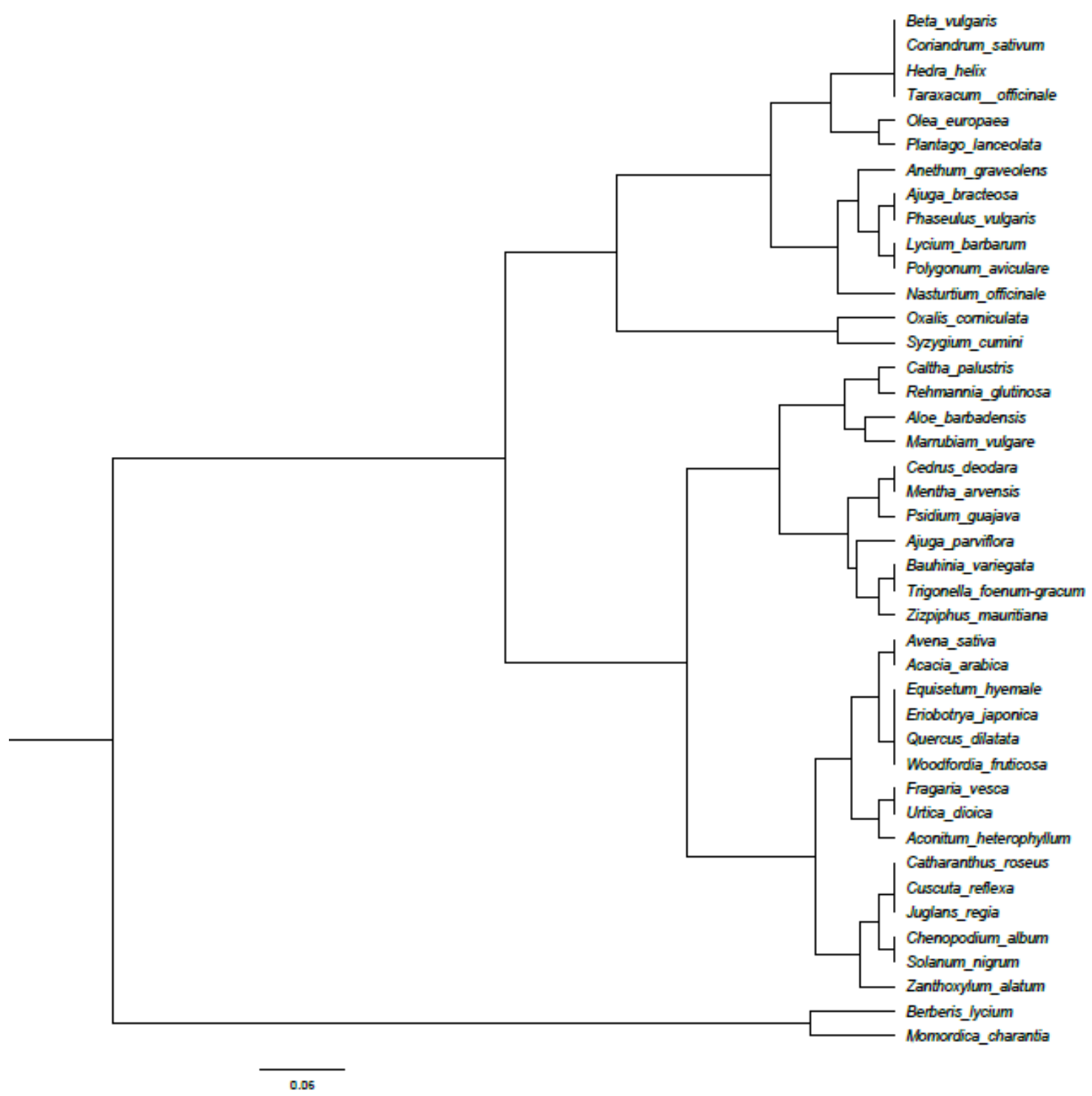

Figure 5. Cluster analysis based on RIF values of plants 
Cluster one comprised of Berberis lycium and momordica charantia. Both species showed close relationship based upon RFC. Cluster two received 41 species, it was the largest group. Cluster two was further divided into 4 sub clades. Beta vulgaris, Coriandrum sativum, Hedra helix and Taraxacum officinale showed closed RFC values. Olea europea and Plantago lanceolata were sister species, showing close association. Anethum graveolens and Nasturtium officinale showed weak association with rest of the species in the clade, i.e. Ajuga bracteosa, Lycium barbarum and Polygonum aviculare. Oxalis corniculata and $S$. cumini were closely associated based on RFC values. $C$. palustris was closely related to $R$. glutinosa. F. vesca, A. dioca and A. hydrophyllum were closely related species. In the next cluster, $C$. reflexa, J. regia, $C$. album and $S$. nigrum were more closely related plant species. In the cluster, $B$. variegata was more closely related $T$. foenum-gracum and $Z$. mauritiana than $A$. parviflora. Whereas $C$. deodara was more closely related to $M$. arvensis than $S$. guajava.

Multivariate cluster analysis, on the basis of FIV, suggested a close relationship among the families. It is divided into two main clusters (Fig. 6). Cluster 1 showed the association of Rosaceae, Equitaceae, Lythraceae and Poaceae. Cluster 2 is further divided into 3 sub clusters. Brassicaceae was most closely related to Polygonaceae. Chenopodiaceae was closed to Urticaceae than Oxalidaceae. Apiaceae and Berberidaceae were more close to each other on the basis of FIV.

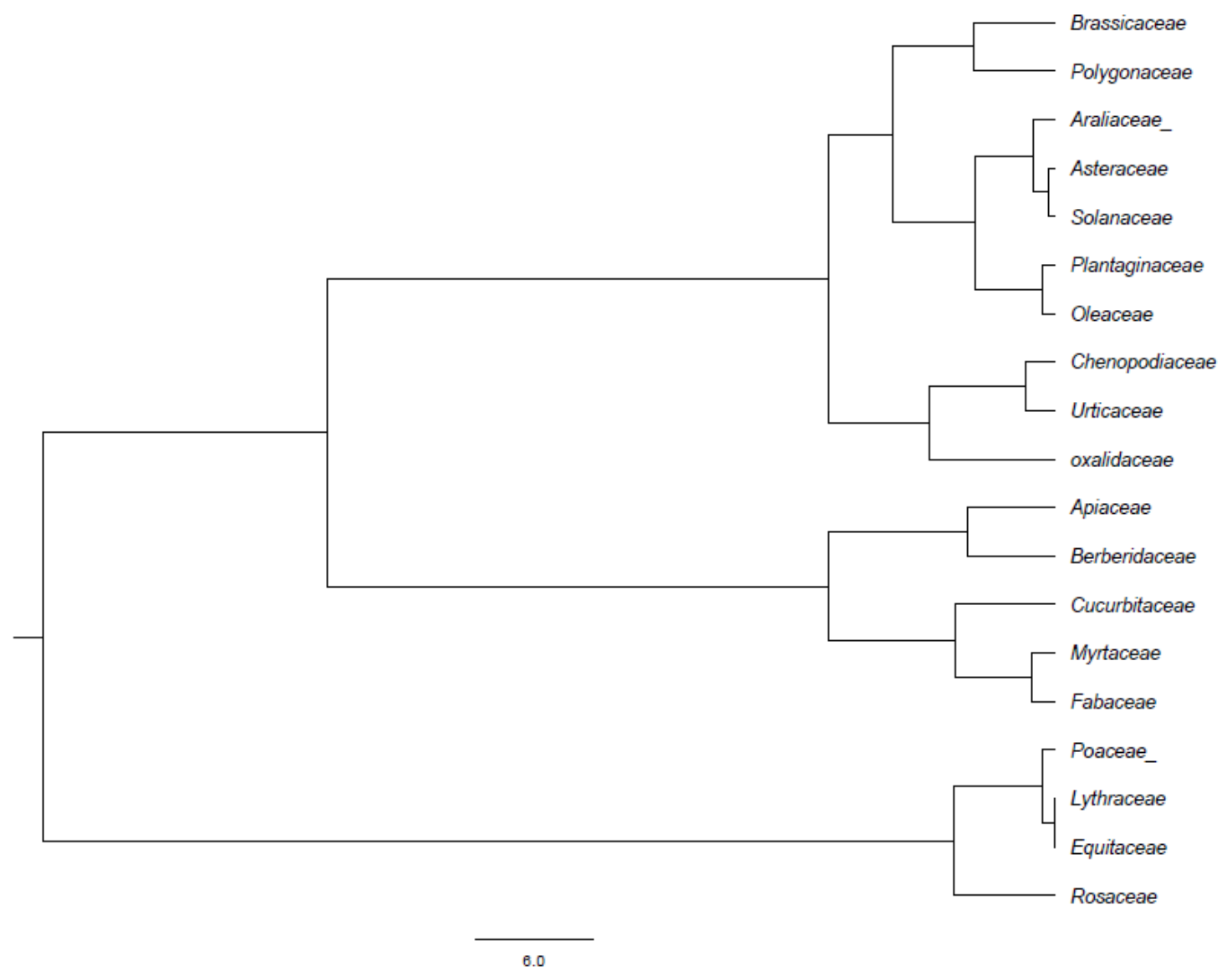

Figure 6. Cluster analysis of families based on FIV 


\section{Discussion}

The present investigation was confined in rural areas of Azad Jammu and Kashmir, Pakistan. The objective was to document the medicinal flora of the area traditionally used for the treatment of diabetes and to explore the constituents of these medicinal plants. To collect the ethnobotanical information, 340 informants were interviewed. There had been tendency of increasing ethnobotanical knowledge with the age of informants. The ethnobotanical data showed that 42 plant species belonging to 41 genera and 30 families were used for the treatment of Diabetes. The reason is that older people are more familiar with the use of medicinal plants and are involving in ethnomedicinal practicing and traditional knowledge. However younger people have less interest in older traditional knowledge regarding the use of plants for treatment of diseases. Previous studies also show that elder people have more ethnomedicinal knowledge (Kpodar et al., 2015; Abouri et al., 2012).

Fabaceae and Lamiaceae were the dominant families in the study area with 4 species each followed by Apiaceae, Chenopodiaceae, Ranunculaceae, Rosaceae and Solanaceae with 2 species each. The dominance of the families is corresponded to the fact that these are well known among the people and easy to access. Furthermore, locals have more knowledge about these families and used these plants for generations to generations. Frequent use of these families also suggests that important secondary metabolites are present in the member of these families. In previous study, it was found that members of Fabaceae and Lamiaceae are used for the treatment of diabetes (Aadhan and Anand, 2017).

Most frequent used plant parts were the leaves, followed by fruits, whole plant, seeds, roots, bark, flowers and aerial parts Leaves are mostly used parts because of the fact that leaves are the main photosynthetic organs and they are the part of the plants which is most easily reachable and accessible throughout the year (Fezon et al., 2008). Leaves are also valuable in phytotherapy because they contain more effortlessly extractable phyto-compounds, crude drugs and several additional mixtures (Bano et al., 2014a, b). Moreover, leaves are easy to collect and process and their collection does not harm the plant considerably in contrast to collection of bark, roots and whole plant (Telefo et al., 2011; Zheng and Xing, 2009). Leaves are most frequent plant parts used as ethnopharmacology as reported in previous studies (Amjad et al., 2017; Khan et al., 2015).

Most frequent used method was decoction followed by extract, juice, vegetable and powder. In ethnobotanical practices, the major forms of herbal drug preparation are the decoction (mixing plant part with water, tea or soup (Amjad et al., 2017). The other reason of the use of decoction is that it is prepared by heating which may hasten the biological reactions resultant in the increased accessibility of many bioactive compounds (Han et al., 2007; Zhang et al., 2005).

The RFC values were from 0.09 to 0.95 . The highest RFC was found for Berberis lycium and Momordica charantia reflected that these species were very famous and familiar among the local inhabitants of the study area and these species could be further investigated for their pharmacological and phytochemical properties (Mukherjee and Wahile, 2006). Number of studies suggests that Momordica charantia has higher potential as antidiabetic (Chaturvedi, 2012; Nama et al., 2011; Shibib et al., 1993; Ali et al., 1993).

Jaccard index results showed ethnobotanical knowledge varied greatly among the communities because of different origins, geography, culture and social behavior. This 
comparison of knowledge may result in discovery of many new drugs (Leonti, 2011). The maximum degree of parallel index was found with studies by Bahmani et al. (2014) from Uramia, Northwest Iran, Ahmad et al. (2009) Attock Pakistan and Kumari et al. (2011) Uttarakhand, India. The highest similarity index corresponds to same type of vegetation and geographical conditions or same ethnic values. Most common species were the Momordica charantia, Trigonella foenum-gracum and Syzygium cumini. These species are found in almost all compared areas, which demonstrate their importance for the treatment of diabetes. The lowest JI was found for the study of Yadav et al. (2012) from Madhya Pradesh, India. This difference is might be due to geographical barriers and different type of vegetation and habitat (Leonti, 2011). Strong positive correlation between UV and RFC showed that increase in number of informants also increases the knowledge of the uses of species (Ishtiaq et al., 2007; Ahmed et al., 2017). This suggested that this study is a significant contribution towards the documentation of plants used for the treatment of diabetes.

\section{Conclusions}

This ethnobotanical study documented the ethnophytotherapeutic management of diabetes mellitus and support of traditional healers in Azad Jammu and Kashmir. The indigenous population still relies to a great extent on traditional healers and medicinal plants to meet their healthcare needs because of the perceived effectiveness, presumed safety with minimal side effects and affordability. In conclusion, this article presented a list of anti-diabetic plants used in the treatment of diabetes mellitus. Medicinal plants are good alternative to synthetic drugs due to biocompatibility, cost effective and less or no side effects. Further studies are needed to be carried out to explore the exact mechanism of these medicinal plants' antidiabetic activity. The documented plants should also be further screening for their phyctochemical constituents, pharmacognostic characters and biochemical assays for their sustainable and effective uses.

Acknowledgements. This study was not funded by any organization. We thank local inhabitants of the study area for their hospitality and cooperation.

\section{REFERENCES}

[1] Aadhan, K., Anand, S. P. (2017): Survey of medicinal plants used for the treatment of diabetes by the Paliyar's Tribe in Sadhuragiri hills, Tamil Nadu, India. - International Journal of Herbal Medicine 5: 17-25.

[2] Abouri, M., El-Mousadik, A., Msanda, F., Boubaker, H., Saadi, B., Askarne, L. (2012): An ethnobotanical survey of medicinal plants used in the Tata Province, Morocco. Journal of Medicinal Plants Research 1: 99-123.

[3] Afshan, N. S., Iqbal, S. H., Khalid, A. N., Niazi, A. R. (2011): Some additions to the Uredinales of Azad Jammu and Kashmir, Pakistan. - Pakistan Journal of Botany 43: 1373-1379.

[4] Ahmad, K. S., Hamid, A., Nawaz, F., Hameed, M., Ahmad, F., Deng, J., Akhtar, N., Wazarat, A., Mahroof, S. (2017): Ethnopharmacological studies of indigenous plants in Kel village, Neelum Valley, Azad Kashmir, Pakistan. - Journal of Ethnobiology and Ethnomedicine 13: 68. DOI: 10.1186/s13002-017-0196-1. 
[5] Ahmad, M., Qureshi, R., Arshad, M., Khan, M. A., Zafar, M. (2009): Traditional herbal remedies used for the treatment of diabetes from District Attock (Pakistan). - Pakistan Journal of Botany 4: 2777-2782.

[6] Ajaib, M., Khan, Z. D. (2014): Ethnobotanical studies of useful trees of District Kotli, Azad Jammu and Kashmir. - Biologia (Pakistan) 60: 63-71.

[7] Ajaib, M., Anjum, M., Malik, N. Z., Siddiqui, M. F. (2015): Ethnobotanical study of some plants of Darguti, tehsil Khuiratta, Azad Jammu and Kashmir. - International Journal of Biological Research 3: 101-107.

[8] Ali, L., Khan, A. K., Mamun, M. I., Mosihuzzaman, M., Nahar, N., Nur-e-Alam, M., Rokeya, B. (1993): Studies on hypoglycemic effects of fruit pulp, seed, and whole plant of Momordica charantia on normal and diabetic model rats. - Planta Medica 59: 408412.

[9] Ali, S. I., Nasir, E. (1970-2002): Flora of Pakistan, National Herbarium, NARC. Islamabad and Department of Botany, University of Karachi, Karachi (Fasc. No. 1-207).

[10] Amjad, M. S., Qaeem, M. F., Ahmad, I., Khan, S. U., Chaudhari, S. K., Malik, N. Z., Shaheen, H., Khan, A. M. (2017): Descriptive study of plant resources in the context of the ethnomedicinal relevance of indigenous flora: A case study from Toli Peer National Park, Azad Jammu and Kashmir, Pakistan. - PLoS ONE 12: e0171896.

[11] Ayodhya, S., Kusum, S., Saxena. Hypoglycaemic activity of different extracts of various herbal plants, - International Journal of Research in Ayurveda and Pharmacy 1: 212-224.

[12] Bahmani, M. I., Zargaran, A., Rafieian-Kopaei, M., Saki, K. (2014): Ethnobotanical study of medicinal plants used in the management of diabetes mellitus in the Urmia, Northwest Iran. - Asian Pacific Journal of Tropical Medicine 71: 348-54.

[13] Bano, A., Ahmad, M., Hadda, T. B., Saboor, A., Sultana, S., Zafar, M., Khan, M. P., Arshad, M., Ashraf, M. A. (2014a): Quantitative ethnomedicinal study of plants used in the skardu valley at high altitude of Karakoram-Himalayan range, Pakistan. - Journal of Ethnobiology and Ethnomedicine 10: 43. DOI: 10.1186/1746-4269-10-4.3 PMID: 24885937.

[14] Bano, A., Ahmad, M., Zafar, M., Sultana, S., Rashid, S., Khan, M. A. (2014b): Ethnomedicinal knowledge of the most commonly used plants from Deosai Plateau, Western Himalayas, Gilgit Baltistan, Pakistan. - Journal of Ethnopharmacology 155: 1046-1052.

[15] Chaturvedi, P. (2012): Antidiabetic potentials of Momordica charantia: multiple mechanisms behind the effects. - Journal of Medicinal Food 15: 101-107.

[16] Donga, J. J., Surani, V. S., Sailor, G. U., Chauhan, S. P., Seth, A. K. (2011): A systematic review on natural medicine used for therapy of diabetes mellitus of some Indian medicinal plants. - Pharma Science Monitor 2: 36-72.

[17] Edwards, S., Nebel, S., Heinrich, M. (2005): Questionnaire surveys: methodological and epistemological problems for field-based ethnopharmacologists. - Journal of Ethnopharmacology 100: 30-36.

[18] Elavarasi, S., Saravanan, K. (2012): Ethnobotanical study of plants used to treat diabetes by tribal people of Kolli Hills, Namakkal District, Tamilnadu, Southern India. International Journal of PharmTech Research 4: 404-411.

[19] Fezan, H. T., Guy, M. I., Kohue, C. C., Mahou, C. H. B. (2008): Etudes de quelques plantes thérapeutiques utilisées dans le traitement de l'hypertension artérielle et du diabète: deux maladies émergentes en Côte d'Ivoire. - Science and Nature 5: 39-48.

[20] Franz, H. (1985): Inhaltsstoffe der Mistel (Viscum album) als potentielle Arzneimittel. Pharmazie 40: 97-104.

[21] Gonza, T. M. R., Casares, P. M., Sanchez, R. C. P., Ramiro, G. J. M., Molero, M. J., Pieroni, A., Giusti, M. E., Censorii, E., De-Pasquale, C., Della, A., ParaskevaHadijchambi, D., Hadjichambis, A., El-Demerdash, M., El-zayat, M., Hmamouchi, M., ElJohrig, S. (2008): Medicinal plants in the Mediterranean area: synthesis of the results of the project RUBIA. - Journal of Ethnopharmacology 116: 341-57. 
[22] Goodman, S. M., Ghafoor, A. (1992): The ethnobotany of southern Balochistan, Pakistan, with particular reference to medicinal plants. - Fieldiana Botany New Series 31: 84.

[23] Han, J., Ye, M., Guo, H., Yang, M., Wang, B. R., Guo, D. A. (2007): Analysis of multiple constituents in a Chinese herbal preparation Shuang-Huang-Lian oral liquid by HPLC-DAD-ESI-MS. - Journal of Pharmaceutical and Biomedical Analysis 44: 430-438.

[24] I. D. F. (2010): The Diabetes Atlas (4th ed). - International Diabetes Federation, Brussels. http://www.diabetesatlas.org.

[25] Ishtiaq, M., Hanif, W., Khan, M. A., Ashraf, M., Butt, A. M. (2007): An ethnomedicinal survey and documentation of important medicinal folklore food phytonyms of flora of Samahni Valley, (Azad Kashmir) Pakistan. - Pakistan Journal of Biological Sciences 10: 2241-56.

[26] Jain, S. P., Singh, S. C., Puri, H. S. (1998): Medicinal plants of Neterhat, Bihar India. International Journal of Pharmacognosy 32: 44-50.

[27] Katiri, A., Barkaoui, M., Msanda, F., Boubaker, H. (2017): Ethnobotanical survey of medicinal plants used for the treatment of diabetes in the Tizi n' Test Region (Taroudant Province, Morocco). - Journal of Pharmacognosy and Natural Products 3: 130.

[28] Khan, M. P. Z., Ahmad, M., Zafar, M., Sultana, S., Ali, M. I., Sun, H. (2015): Ethnomedicinal uses of Edible Wild Fruits (EWFs) in Swat Valley, Northern Pakistan. Journal of Ethnopharmacology 173: 191-203.

[29] Kpodar, M. S., Lawson-Evi, P., Bakoma, B., Eklu-Gadegbeku, K., Agbonon, A., Aklikokou, K., Gbeassor, M. (2015): Ethnopharmacological survey of plants used in the treatment of diabetes mellitus in south of Togo (Maritime Region). - Journal of Herbal Medicine 5: 147-152.

[30] Kumari, P., Joshi, G. C., Tewari, L. M. (2011): Contribution of indigenous anti-diabetic flora in Almora district, Uttarakhand, India. - Current Botany 2: 01-07.

[31] Leonti, M. (2011): The future is written: impact of scripts on the cognition, selection, knowledge and transmission of medicinal plant use and its implications for ethnobotany and ethnopharmacology. - Journal of Ethnopharmacology 134: 542-55.

[32] Mahmood, A., Mahmood, A., Shaheen, H., Qureshi, R. A., Sangi, Y., Gilani, S. A. (2011): Ethno-medicinal survey of plants from district Bhimber Azad Jammu and Kashmir, Pakistan. - Journal of Medicinal Plants Research 5: 2348-2360.

[33] Masika, P. J., Afoloayan, A. J. (2003): An ethnobotanical study of plants used for the treatment of livestock diseases in the Eastern Cape Province South Africa - Journal of Pharmaceutical Biology 41: 16-21.

[34] Molares, S., Ladio, A. (2009): Ethnobotanical review of the Mapuche medicinal flora: Use patterns on aregional scale. - Journal of Ethnopharmacology 122: 251-260.

[35] Mossa, J. S. (1999): A study on Arabian folk medicine. - International Journal of Crude Drugs Research 23: 137-145.

[36] Mukherjee, P. K., Wahile, A. (2006): Integrated approaches towards drug development from Ayurveda and other Indian system of medicines. - Journal of Ethnopharmacol 103: 25-35.

[37] Namsa, N. D., Mandal, M., Tangjang, S., Mandal, S. C. (2011): Ethnobotany of the Monpa ethnic group at Arunachal Pradesh, India. - Journal of Ethnobiology and Ethnomedicine 7: 31. DOI: 10.1186/1746-4269-7-31.

[38] Ocvirk, S., Kistler, M., Khan, S., Talukder, S. H., Hauner, H. (2013): Traditional medicinal plants used for the treatment of diabetes in rural and urban areas of Dhaka, Bangladesh - an ethnobotanical survey. - Journal of Ethnobiology and Ethnomedicines 9: 43.

[39] Qamar, Z. Q., Anwar, M., Dar, N. I., Ali, U. (2010): Ethno-botanical study of wild medicinal plants of Neelum Valley, Azad Jammu and Kashmir, Pakistan. - Pakistan Journal of Wildlife 1: 25-30. 
[40] Shaheen, H., Shinwari, Z. K., Qureshi, R. A., Zahidullah (2012): Indigenous plant resources and their utilization practices in village population of Kashmir Himalayas. Pakistan Journal of Botany 44: 739-745.

[41] Shibib, B. A., Khan, L. A., Rahman, R. (1993): Hypoglycaemic activity of Coccinia indica and Momordica charantia in diabetic rats: depression of the hepatic gluconeogenic enzymes glucose-6-phosphatase and fructose-1,6-bisphosphatase and elevation of both liver and red-cell shunt enzyme glucose-6-phosphate dehydrogenase. - Biochemical Journal 292: 267-270.

[42] Shinwari, M. I., Shinwari, M. I. (2010): Botanical Diversity in Pakistan; Past, Present and Future. - Proc. Workshop World Environment Day, Lahore.

[43] Tardio, J., Pardo-de-Santayana, M. (2008): Cultural importance indicates: a comparative analysis based on the useful wild plants of Southern Cantabria (Northern Spain). Economic Botany 62: 24-39.

[44] Telefo, P. B., Lienou, L. L., Yemele, M. D., Lemfack, M. C., Mouokeu, C., Goka, C. S., Tagne, S. R., Moundipa, F. P. (2011): Ethnopharmacological survey of plants used for the treatment of female infertility in Baham, Cameroon. - Journal of Ethnopharmacology 136: $178-187$.

[45] Wei, M., Gibbons, L., Mitchell, T., Kampert, J., Blair, S. (2010): Alcohol intake and incidence of type 2 diabetes in men. - Diabetes Care 23: 18-22.

[46] World Health Organization (2016): Global Report on Diabetes. - WHO, Geneva, Switzerland.

[47] Yadav, M., Khan, K. K., Beg, M. Z. (2012): Medicinal plants used for the treatment of diabetes by the Baiga tribe living in Rewa District M. P. Ind. - Journal of Life Science 2: 99-102.

[48] Yokozawa, T., Kim, H. Y., Cho, E. J., Yamabi, N., Choi, J. S. (2003): Protective effects of mustard leaf (Brassica juncea) against diabetic oxidative stress. - Journal of Nutritional Science and Vitaminology 49: 87-93.

[49] Zhang, J. L., Cui, M., He, Y., Yu, H. L., Guo, D. A. (2005): Chemical fingerprint and metabolic fingerprint analysis of Danshen injection by $\mathrm{HPLC} \pm \mathrm{UV}$ and $\mathrm{HPLC} \pm \mathrm{MS}$ methods. - Journal of Pharmaceutical and Biomedical Analysis 36: 1029-1035.

[50] Zheng, X. L., Xing, F. W. (2009): Ethnobotanical study on medicinal plants around Mt. Yinggeling, Hainan Island, China. - Journal of Ethnopharmacology 124: 197-210. 


\section{APPENDIX}

\section{Questionnaire for collecting ethnomedicinal data during Ethnobotanical Study \\ Questionnaire: \\ Informants' consent for the participation in the study:}

I............................................. (name of informant) hereby give my full consent and conscious to participate in this study and declare that to the best of my knowledge the information that I have provided are true, accurate and complete.

Date.

(Signature/Thumb impression of Informant)

\section{Informants' details:}

Name.

Gender.

Age.

Occupation.

Education.

Location/Residence.

Data about medicinal plant and its use:

Plant (Local name)

Habit (Tree/Herb/Shrub/Climber/......)

Plant part used

Cultivated/Wild

If cultivated, cultivated for.

If wild, availability in natural resources (easy/difficulty/very difficult)

Conservation needs

Conservation efforts made by Government and local residents

Method of collection and storage

Name of disease(s) treated.

Method of crude drug preparation.

Mode of administration.

Dosage.....

Other uses (if any)

\section{Remarks:}

Plant identified as (Botanical name and family)

Information provided by informants will be used for research purposes only 